\title{
The Effect of Zinc Oxide Dust and Environmental Conditions of Training Ground on Lung Forced Vital Capacity Conditions of Central Java Weighthlifting Athletes
}

\author{
Hadi $^{1}$, Mustafa Daru Affandi ${ }^{2}$, Syahru Romadhoni ${ }^{3}$ \\ \{hadi_pabbsi@mail.unnes.ac.id ${ }^{1}$, daru.affandi@gmail.com² ${ }^{2}$ syahru_fik@mail.unnes.ac.id ${ }^{3}$ \} \\ Universitas Negeri Semarang, Semarang, Indonesia ${ }^{1,2,3}$
}

\begin{abstract}
For an athlete, training is an activity that must be done routinely. In training and competition, weightlifting requires chemicals that are used to get rid of slippery hands when lifting weights. That is Zinc Oxide. The poor condition of the training ground causes a decrease in the quality of the physiology of the lungs of the athletes. One reason is that it is sourced from Zinc Oxide dust used during training. Pulmonary physiological disorders were analyzed from Forced Volume Capacity values using a digital spirometer with standard ETS / ARS standard. The sudy result levels of particle dust 17, $921 \mathrm{mg} / \mathrm{m} 3$ which exceeds Threshold. From pulmonary physiology measurements, $33.33 \%$ of athletes suffer from mild restriction and decrease in pulmonary physiology caused by high levels of Zinc Oxide at the training ground.
\end{abstract}

Keywords: zinc oxide dust, pulmonary physiology, weightlifting athletes.

\section{Introduction}

The training center is the second home for an athlete. Where in the training center physical exercise activities are carried out, technical training to the evaluation of the exercise. Comfort in the practice room must be considered. This comfort in terms of physical conditions such as room temperature, humidity, lighting, dust cleanliness in the training room. With the comfort of a comfortable place to practice, it is expected that altets can practice with focus without being disturbed by the conditions of the place to practice. In addition, the condition of the training ground can affect the physical condition of athletes in the short and long term.

.In the XXth PON which will be held in Papua Province in 2020, Weightlifting is one of the flagship sports contingents of the Central Java province that is contested among 37 other sports. And as many as 21 athletes from the Great Weight Lifting Association, Bodybuilding, Indonesian Weightlifting (PABBSI) who participated in the prequalification, 13 athletes $(62 \%)$ passed and were entitled to participate in PON XX.

The presence of excessive dust levels in the exercise room air in addition to disrupting the quality of short-term health can also cause disease if exposed for a long time. According to [1] SNI-19-0232-205 it was mentioned that the Zinc Oxide dust threshold value in the room 
was $10 \mathrm{mg} / \mathrm{m} 3$ air. If it exceeds $10 \mathrm{mg} / \mathrm{m} 3$, treatment must be taken so that the dust does not interfere with the health of the athletes.

In spirometry measurements on workers exposed to lime dust with exposure concentrations above $3 \mathrm{mg} / \mathrm{m} 3$, it was found that more than $50 \%$ of workers experienced mild, moderate to severe pulmonary physiology [2] In other studies, there was a relationship between vital lung capacity and cardiorespiratory. This relationship means that with the better vital capacity of the lungs the athlete can have stable endurance. (Ilman alifa 2016) [3]. In other studies the effect of vital lung capacity on swimming ability was $79.2 \%$ [4]. This shows that good lung physiology values greatly affect the stamina of the aatlet in various sports.

From this basis, researchers want to look for the influence of dust and the environment of the training ground on weight lifters and weightlifting Central Java. So that the results of this study obtained an overview and causes of decreased athlete stamina and obtained solutions so that the quality of athletes does not decrease.

\section{Methods}

This type of research is analytic observation research. Research uses case and control groups. Where each group gets the same treatment and testing. In the case group are the Central Java Weightlifting athletes who will be compared with the KONI National Weightlifting athletes. The sample size used is the total sample. Where all athletes will be used as respondents.

In the pulmonary physiology parameter, each respondent both controls and cases will be measured using a digital spirometer. The tool used with the Digital Pony Fx brand Digital spirometer. This tool is able to measure the values of various pulmonary physiology parameters, but in this study only tested with KVP, FEV, FEV 1. Testing on digital spirometry will produce values, comparison of values and standards, and the interpretation of results in the form of Normal, Mild Disorders, Moderate Disorders, or IRON Interference. This assessment tool automatically calculates from the factors of Gender, Age, IRON Body, Height, smoking habits or not.

Spirometry is a physiological test that tests measuring levels the maximum volume of air that can reach when maximum inspiration and expiration. the most important parameter in measuring spirometry is FVC. FVC is the total volume of air that can be released by force and as much as possible by respondents whose assessment in a digital spirometer starts from the full inspiration stage. Whereas FEV1 is the expiratory volume in the first second of the FVC. The ATS ERS standard covers the measurement of FEV1 [5] but by testing the FEV in the first 6 seconds it can also be used as a reference for a decrease in the vital capacity of the lungs [6]

Spirometry measurement also requires data on the physical condition of the respondent namely body weight, height, smoking habits, ethni, gender. This is needed in filling the data on the spirometer [7].

In testing the level of environmental dust using a High Volume Sample that can suck up to 500 liters of air / minute. While the filter paper used is TFA with a pore diameter of 10 microns the constant weight is obtained by drying at 131 and repeated until the constant weight is obtained, if the difference in weight of the first and second weightings does not exceed $0.2 \mathrm{mg}$.. The dust value is calculated from dust captured on filter paper and calculated using the gravimetric method. 
Testing the dust levels of the exercise room was carried out 3 times at each location before the exercise and during the exercise. Difference in value of room dust in before and during exercise is the value of dust from training activities [8].

Environmental measurements are carried out by measuring the temperature and humidity conditions in the training environment. Measurement using environmental tests which can measure temperature and humidity in real time.

\section{$3 \quad$ Results and discussions}

\subsection{Dust levels}

In measuring dust levels at the study site. Obtained dust levels before use for exercise is an average of $1.35 \mathrm{mg} / \mathrm{M}^{3}$. where this condition is still in good condition for the training ground. But when used for training, dust is increased by an average of $17 \mathrm{mg} / \mathrm{m} 3$. this value exceeds the Quality Standards of $10 \mathrm{mg} / \mathrm{m} 3$ [9]. this has the potential to cause health problems in athletes if exposed for a long time. From this data it means that the main source of dust in the air of the training room is coming from weight lifting. Where this exercise process uses Zinc oxide which is used by athletes to prevent slippery and sweat on the hands when lifting weights.

High levels of dust in the room due to the absence of air filters that function to filter the air that contains dust and produce clean air. The absence of an air filter is also made worse by the lack of air circulation in the room. One method of cleaning the air that can be used is a cyclone. R.D Ratnani, 2008 [10] explains that air pollution control techniques using a cyclone system have an effectiveness of up to $95 \%$ for particles with a diameter of 5-20 microns.

\subsection{Measurement of comfort from athletes}

Measurements were made using a questionnaire form, where from the questionnaire results of the athletes as many as $14,3 \%$ felt uncomfortable with environmental conditions. Discomfort is felt due to lack of ventilation, air temperature and humidity levels that are not conducive as a weightlifting exercise site [11].

$85.7 \%$ of the athletes were disturbed by the dust conditions in the practice room and consequently $57.1 \%$ of the athletes felt shortness of breath after practicing in the practice room. 


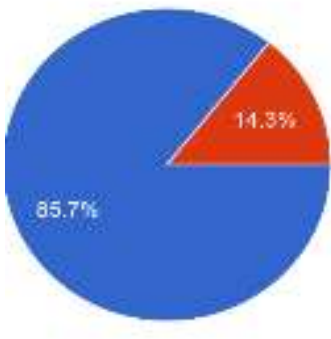

Fig. 1.

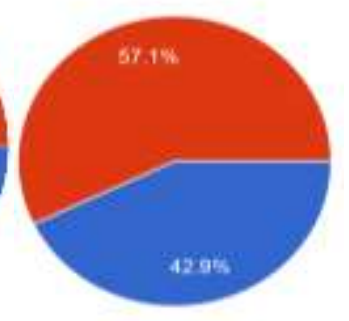

Fig. 2.

Fig 1. shows the percentage of athletes' comfort in the Exercise Room

Fig 2. shows the percentage of shortness of breath in the practice room

\subsection{The condition of the lungs}

All respondents are weight lifting athletes who have more than 5 years' training time. Overall athletes have a good level of nutrition. $1 / 3$ of total respondents have mild disorders. This mild disturbance is found in athletes who have 5-10 years of practice time. Not yet found athletes who have moderate to severe disorders. From the examination results found 33, 33\% of respondents experienced mild restrictions. others have normal FVC values. Of all respondents none had obstruction. Even though the athletes only train for 3 hours per day and 5 times a week, it seems that the training ground that is not good has greatly impacted the physiology of the lungs [12].

Complaints that occur in athletes are the condition of being tired and not strong enough to do repetition or repetition. In athletes who have normal lung conditions, symptoms of fatigue do not occur.

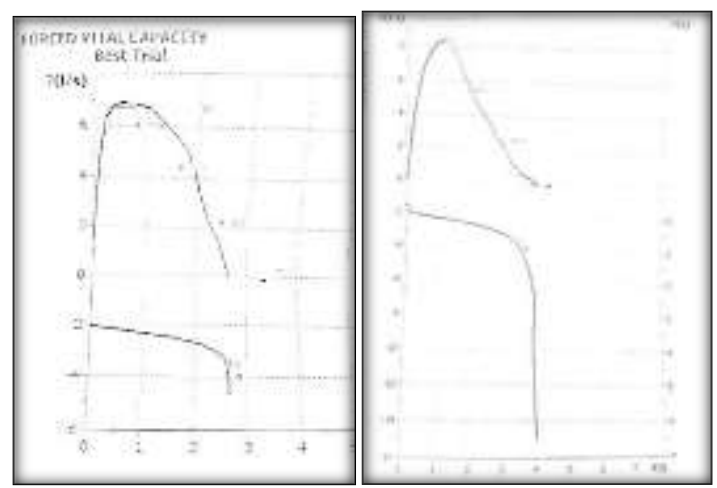

Fig. 3.

Fig. 4.

Fig 3. is Midle restriction spirometry graphic

Fig 4. is Normal Spirometry Graphic 
From the picture shown, in midle restriction, the flow value only reaches a peak at value $6 \mathrm{l} / \mathrm{s}$, whereas in normal lungs a higher flow value is obtained above $8 \mathrm{l} / \mathrm{s}$. In addition, the amount of air volume released there is also a significant difference in athletes who experience restrictions is only able to reach 3 liters. Different from normal lungs can reach 4 liters with expiratory flow values up to $141 / \mathrm{s}$ [13].

Ventilation disorders consist of restriction disorders and obstruction disorders. Restriction is a disruption to lung development by any cause. On interference restriction, the lungs become stiff so that the attraction inside bigger then the chest wall shrinks. Pulmonary volume be washing and narrowing the ribs. As the measured parameter is VC. Normal VC value $80 \%-120 \%$ prediction. VC is less than $80 \%$ of the predicted value considered a restriction disorder. VC is more than $120 \%$ value prediction is a state of over or hyperinflation. In obstruction disorders, indicate the existence decreased expiratory flow velocity and vital capacity normal. In obstruction, the air flow is more intense. On obstruction [14].

Table 1. spirometry testing

\begin{tabular}{lllll}
\hline Parameter & Normal & Obs & Res & Comb \\
\hline FVC & $\geq 80 \%$ Pred $(\mathrm{N})$ & $\mathrm{N}$ & $<\mathrm{N}$ & $<80 \%$ Pred \\
FEV1 & $\geq 80 \%$ Pred $(\mathrm{N})$ & $<\mathrm{N}$ & $\mathrm{N} /<\mathrm{N}$ & $<80 \%$ Pred \\
FEV1/FVC & $\mathrm{N}(>70 \%)$ & $<70 \%$ & $>70 \%$ & $<70 \%$ \\
FVC/FVC Pred & $\geq 80 \%$ & & $<\mathrm{N}$ & \\
\hline
\end{tabular}

Table 2. Spirometry category

\begin{tabular}{lll}
\hline Categori & Restriction & Obstruction \\
\hline Normal & $>80 \%$ & $>80 \%$ \\
mild & $70-79$ pred FVC & $70-79$ pred FEV1 \\
Mild-midle & $60-69 \%$ Pred FVC & $60-69 \%$ FEV1 \\
heavy & $35-49 \%$ Pred FVC & $35-49 \%$ FEV1 \\
Very heavy & $<35 \%$ Pred FVC & $<35 \%$ Pred FEV1 \\
\hline
\end{tabular}

Allegations of a very strong influence of dust levels at the training ground that affected the condition of the lungs of athletes were strengthened in statistical tests. Based on the regression test, the results of the exercise were obtained

$$
Y=a+\beta_{1} X_{1}++\beta_{2} X_{2+} \ldots+\beta_{k} X_{k}
$$

With $\mathrm{a}=-48,856, \beta \_1=7,269$, and $\beta \_2=95,846$. It can be seen that the regression equation is:

$Y=-48,856+7,269 X \_1+95,846 X \_2$

Based on the above calculation, the regression coefficient interpretation is as follows :

1. The constant value $a=-48,856$ means that if all the variables of the environmental conditions of the training ground and the effect of zinc oxide have not changed, the total lung physiology condition is $-48,856$. This value has a negative effect, meaning that there is a decrease in the number of pulmonary physiology conditions by $-48,856$ if the environmental conditions of the training ground and zinc oxide increase.

2. Coefficient value $\beta_{-} 1=7.269$ means that if the environmental conditions at the training site have increased 1 unit, then the variable environmental conditions with the condition 
of pulmonary physiology is positive. Means the resulting condition of the pulmonary physiology shrinking or decreasing

3. Coefficient value $\beta \_2=95,846$ means that if the condition of the influence of zinc oxide has increased by 1 unit, then the variable condition of the influence of zinc oxide with pulmonary physiology is positive. Means the resulting condition of the pulmonary physiology shrinking or decreasi

Based on the probability value, it is known that the environmental conditions of the training ground with the influence of zinc oxide obtained a value of $0.756>0.05$, then there is no significant correlation. It is also known, that the environmental conditions of the training ground with the condition of the lung physiology obtained $0.982>0.05$, then there is also no significant correlation.

\section{Conclusions}

Condition of Dust in the training ground affects the physiology of the athlete's lungs, although currently the disturbance is still in a mild level, but will be at high risk if there is no improvement in environmental conditions. Lack of air circulation and the absence of air filters, causing the accumulation of zinc dust in the exercise room. This makes the athlete feel uncomfortable with the training conditions.

The further research needs the air filters and exhaust fans are provided to clean dust inside the training ground and make air circulation better. The need for periodic measurements of the condition of the pulmonary athlete's weight lifting so that health disorders can be monitored due to the exercise process

\section{References}

[1] Badan Standarisasi Nasional. Nilai Ambang Batas ( NAB ) zat kimia di udara tempat kerja [Internet]. Nilai ambang batas (NAB) zat kimia di udara tempat kerja. 2005.

[2] Bährle-Rapp M, Bährle-Rapp M. Zinc Undecylenate. Springer Lex Kosmet und Körperpfl. 2007;(6):601-601.

[3] Bakhtiar A, Amran WS. Faal Paru Statis. J Respirasi. 2019;2(3):91.

[4] Bakhtiar A, Tantri RIE. Faal Paru Dinamis. J Respirasi. 2019;3(3):89.

[5] Beckett WS, Chalupa DF, Pauly-Brown A, Speers DM, Stewart JC, Frampton MW, et al. Comparing inhaled ultrafine versus fine zinc oxide particles in healthy adults: A human inhalation study. Am J Respir Crit Care Med. 2005;171(10):1129-35.

[6] Graham BL, Steenbruggen I, Barjaktarevic IZ, Cooper BG, Hall GL, Hallstrand TS, et al. Standardization of spirometry 2019 update an official American Thoracic Society and European Respiratory Society technical statement. Am J Respir Crit Care Med. 2019;200(8):E70-88.

[7] Graham BL, Steenbruggen I, Barjaktarevic IZ, Cooper BG, Hall GL, Hallstrand TS, et al. Standardization of spirometry 2019 update an official American Thoracic Society and European Respiratory Society technical statement. Am J Respir Crit Care Med. 2019;200(8):E70-88.

[8] Ilmu B, Komunitas K, Kedokteran F, Kesehatan I, Jambi U. Penyakit Sistem Respirasi Akibat Kerja Armaidi Darmawan. :68-83. 
[9] Mubarok W, Kumaidah E, Supatmo Y. Perbedaan Nilai Vital Capacity, Forced Vital Capacity Dan Forced Expiratory Volume in One Second Antar Cabang Olahraga Pada Atlet Usia 6-12 Tahun. J Kedokt Diponegoro. 2015;4(4):1619-25.

[10] Mubarok W, Kumaidah E, Supatmo Y. Perbedaan Nilai Vital Capacity, Forced Vital Capacity Dan Forced Expiratory Volume in One Second Antar Cabang Olahraga Pada Atlet Usia 6-12 Tahun. J Kedokt Diponegoro. 2015;4(4):1619-25.

[11] Ratnani R. Teknik Pengendalian Pencemaran Udara Yang Diakibatkan Oleh Partikel. J Momentum UNWAHAS. 2008;4(2):114195.

[12] Ruppel GL. Spirometry. Respir Care Clin N Am. 2014;3(2):155-81.

[13] Syahda IA, Damayanti I, Imanudin I. Hubungan Kapasitas Vital Paru-Paru Dengan Daya Tahan Cardiorespiratory Pada Cabang Olahraga Sepak Bola. J Terap Ilmu Keolahragaan. 2016;1(1):24.

[14] Vandevoorde J, Verbanck S, Schuermans D, Broekaert L, Devroey D, Kartounian J, et al. Forced vital capacity and forced expiratory volume in six seconds as predictors of reduced total lung capacity. Eur Respir J. 2008;31(2):391-5. 